DOI https://doi.org/10.30525/978-9934-26-008-7.2-7

\title{
THE SUGGESTIONS FOR IMPROVING THE EFFICIENCY OF DETECTING LOW-VISIBILITY AIR OBJECTS THROUGH USING OF THE PASSIVE RECEIVERS MULTI-POSITION SYSTEM
}

\section{Misiyuk G. V., Popov S. E.}

\section{INTRODUCTION}

Reliable air defense of the state is impossible without the creation of an effective airspace control system. The basis of the state airspace control system is the Radio Troops (RT). They provide the creation of radar field (RF) in the airspace.

Airspace control consists of continuous monitoring by radars, aircraft flights and determination of their affiliation by means of state identification. Airspace control is carried out in radar detection zones, as well as additional radars that are included for airspace control and inspection.

Controlling the airspace is greatly complicated by the appearance of small air objects $(\mathrm{AO})^{1}$.

AO has specific flight characteristics:

- small effective scattering area (ESA);

- wide range of speeds;

- implementation of covert flights at medium, low and extremely low altitudes using the terrain.

Features of radar detection of small AO (on the example of unmanned aerial vehicles (UAVs)) are:

- short detection range;

- finding the UAV in the area of illumination from local objects, which requires the inclusion of equipment for protection against passive interference, which, in turn, reduces the detection range;

1 Ковалевський С.M,. Худов Г.В,. Боровий В.I. Перспективи розвитку засобів повітряного нападу як об'єктів радіолокаційного виявлення. Системи озброєння та військова техніка. 2014. Вип. № 4(40). С. 31-35. 
- lack of notification of UAV actions from other air surveillance control systems due to the fact that UAVs usually operate in the area of only one air surveillance control system.

Traditional (known) organizational and technical ways to increase the efficiency of airspace control of inconspicuous and $\mathrm{AO}$ are:

- increase of energy potential and improvement of tactical and technical characteristics (TTC) of radar;

- compaction of the radar location in dangerous;

- simultaneous use of radars of different frequency and others.

The use of traditional methods to increase the efficiency of airspace control of AO leads to an increase in the required number of radars, increase in power consumption and, as a consequence, to an increase in the cost of creating and maintaining a radar field (RF). Alternative (promising) ways to increase the efficiency of detection of inconspicuous and $\mathrm{AO}$ are $^{2}$ :

- use of energy from external radiation sources and implementation of spaced reception modes;

- the use of the properties of the resonant reflection of electromagnetic waves from the $\mathrm{AO}$ when using wavelengths that are comparable to the size of the AO;

- use of multi-position system, etc.

Thus, at present, in solving the problem of detecting $\mathrm{AO}$, the contradiction between the trends in the development of inconspicuous $\mathrm{AO}$ and the capabilities of existing radars for inconspicuous $\mathrm{AO}$ has intensified.

- use of energy from external radiation sources and implementation of spaced reception modes;

- the use of the properties of the resonant reflection of electromagnetic waves from the $\mathrm{AO}$ when using wavelengths that are comparable to the size of the AO;

- use of multi-position system, etc.

Thus, at present, in solving the problem of detecting $\mathrm{AO}$, the contradiction between the trends in the development of inconspicuous $\mathrm{AO}$ and the capabilities of existing radars for inconspicuous AO.

${ }^{2}$ Ковалевський С.М, Пєвцов Г.В., Худов Г.В. Пропозиції щодо створення скритого маловисотного радіолокаційного поля в умовах ведення сучасних мережецентричних та гібридних війн. Наука $i$ техніка Повітряних Сил Збройних сил Украӥни. Харків : ХУПС, 2015. Вип. № 1 (18). С. 77-81. 


\section{Analysis of the capabilities of radars for the detection of low-visibility air objects}

Technical advances in recent years have affected both the appearance of weapons and their functionality. Thus, in modern hostilities cannot do without the use of UAV, which have proven their effectiveness in the Donbass and in the military conflict between Armenia and Azerbaijan ${ }^{3}$.

AO (UAV) is characterized by small geometric dimensions, low thermal contrast and flight speed, as well as low ESA, which does not allow for sufficiently effective detection. The reduction in radar visibility of AO is inextricably linked to a reduction in their ESA.

The main methods of reducing the ESA are reducing the size, giving objects special reflective forms, the use of active masking systems, radio-absorbing coatings and composite materials ${ }^{4}$. These features significantly complicate the task of detecting AO using existing radar. The detection of such objects is complicated by the fact that they are used at low or extremely low altitudes using the terrain. At present, UAVs are a rather serious problem. In fact, the most logical way to get rid of an enemy drone is to destroy it. At the same time, various weapons can be used for destruction ${ }^{5}$.

Small light UAVs (and the vast majority of those used, for example, in the Donbass) can be shot down with small arms, which has been proven repeatedly, but this required enormous effort and consumption of ammunition, while actually getting into the device did not guarantee its downing (known cases of UAV losses showed damage to the engine or battery).

Alternative means of destroying UAVs can be anti-aircraft guns, which can create a fairly high density of fire.

During the conflict in Donbass, the mass use of modern Russianmade UAVs by illegal armed groups, which were actively used to

\footnotetext{
${ }^{3}$ Чепурний В.А, Бардаков М.В., Худов Г. В. Аналіз тенденцій розвитку та застосування розвідувальних безпілотних апаратів у сучасних мережецентричних та гібридних війнах. Наука і техніка Повітряних Сил Збройних сил Украӥни. Харків : ХНУПС, 2015. Вип. № 4 (21). С. 24-28.

${ }^{4}$ Романченко I.C. Теорія і практика боротьби 3 малорозмірними низьколітними цілями (оцінка можливостей, тенденції розвитку засобів протиповітряної оборони) : монографія / О.М. Загорка, С.Г. Бутенко, О.В. Дейнега. Житомир. 2011. С. 344.

5 Ерёмин Г.В. Малоразмерные беспилотники - новая проблема для ПВО. Тамбов, 2015. URL: http://www.armynews.ru/2015/02/malorazmernye-bespilotnikinovaya-problema-dlya-pvo.
} 
establish radio interference and perform other special tasks, was recorded ${ }^{6}$.

For example, the use of Russian UAVs of such types as "Orlan-10", "Dozor-100", "Dozor-600", "Granat-4", "Outpost" with a depth of reconnaissance up to $300 \mathrm{~km}$. These aircraft take off from the territory of Russia 15-20 km to the state border. Their stay can be up to 16 hours. In addition, unidentified tactical UAVs with a depth of up to 5-10 km are used. We will conduct a detailed analysis of these and other UAVs ${ }^{7}$.

Reconnaissance small complex "Seeker" (Figure 1) today - the only portable short-range complex.

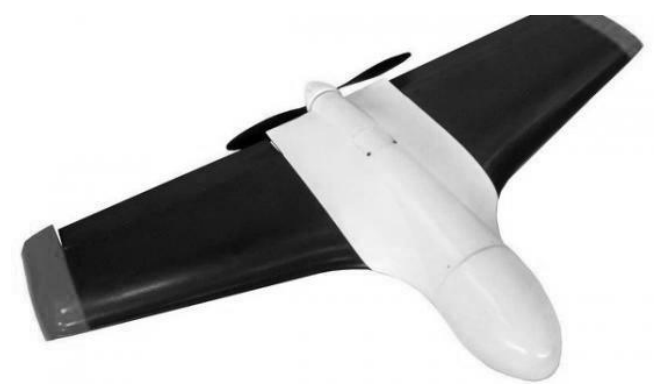

Fig. 1. Reconnaissance UAV T-4 reconnaissance small complex "Seeker"

The main purpose - an individual means of airspace control. The main developer is the international corporation "Development", the work is carried out at the Omsk Radio Plant. The whole complex will be placed in one container (type GK-30), the total weight will not exceed $10 \mathrm{~kg}^{8}$. The peculiarity of the communication with the UAV in the air is the use of a retractable antenna from a portable backpack, which does not tie the paratroopers to the place of installation of a stationary remote antenna.

${ }^{6}$ Сухаревський О.І., Василець В.О., Ряполов І.С. Оцінювання параметрів зон виявлення безпілотного літального апарату «Орлан-10» радіолокаційними засобами самохідного зенітного ракетного комплексу 9К33М3 «Oca-АКМ». Системи озброєння і військова техніка. 2016. Вип. № 4(48). С. 13-18.

7 Алімпієв А.М. Довідник учасника АТО: озброєння і військова техніка Збройних сил Російської Федерації. / Г.В. Пєвцов, Д.А. Гриб та ін. ; за заг. ред. А.М. Алімпієва. Харків. 2015. 732 с.

${ }^{8}$ Алімпієв А.М. Довідник учасника АТО: озброєння і військова техніка Збройних сил Російської Федерації. / Г.В. Пєвцов, Д.А. Гриб та ін. ; за заг. ред. А.М. Алімпієва. Харків. 2015. 732 с. 
Intelligence complex "Seeker" contains:

- base station with antenna;

- tablet computer;

- at least two T-4 UAVs.

UAVs are used to ensure airspace control and information collection within a radius of $8 \mathrm{~km}$. The main purpose of the UAV is to accurately determine the coordinates of objects and adjust the fire. UAV complex "Pear" (Figure 2) - a Russian development, used by special forces. Each UAV is equipped with two digital cameras that can capture images in the visual range.

"Pear" is equipped with an electric two-bladed engine and can be in the air for about an hour and a half. During this time, the device can cover ten kilometers at an altitude of five hundred to a thousand meters and return. Working range 5-10 km, working height is $50-3000 \mathrm{~m}$ above the level of the underlying surface, but most often the devices are used at altitudes of 100-500 meters ${ }^{9}$. The only obstacle to work can be the wind, the speed of which during start-up should not exceed $12 \mathrm{~m} / \mathrm{s}$ (with gusts up to $15 \mathrm{~m} / \mathrm{s}$ ).

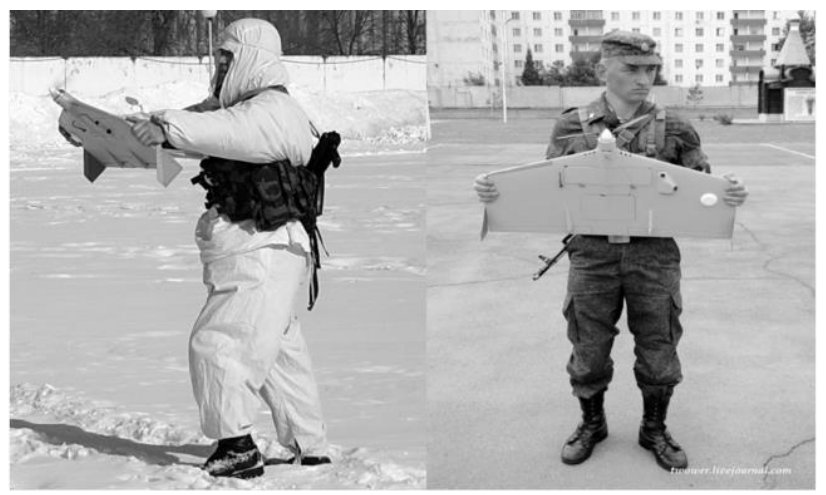

Fig. 2. "Pear" at startup

Video signal transmission is possible only under conditions of direct visibility; when working in mountainous areas it is better to use an information storage device. Time of continuous stay in the air - 75 minutes.

9 Алімпієв А.М. Довідник учасника АТО: озброєння і військова техніка Збройних сил Російської Федерації. / Г.В. Пєвцов, Д.А. Гриб та ін. ; за заг. ред. А.М. Алімпієва. Харків. 2015. 732 с. 
Provides reception and transmission in real time of television and thermal imaging images of the area, determines the coordinates of the objects of observation, performs the functions of a repeater, collects, accumulates and processes information.

Tactical unmanned aerial vehicle ZALA 421-16 (Figure 3) is a dualpurpose complex and solves the problem of remote monitoring, observation in a wide range of weather conditions of the underlying surface (including complex terrain, water surface), search and detection of objects.

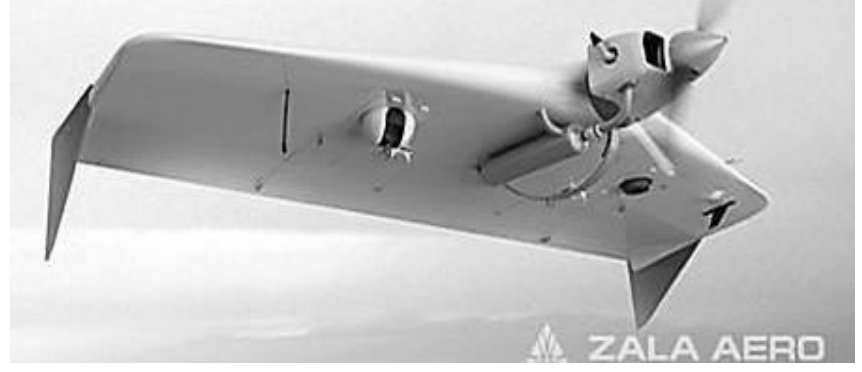

Fig. 3. UAV ZALA 421-16

The ZALA 421-16 UAV complex is an effective means of conducting large-scale aerial photography. UAVs can be used for airspace control and surveillance, targeting, and fire adjustment. This model of UAV in its class has a high duration of continuous flight 4 hours (with a two-stroke engine) and 8 hours (with a four-stroke engine) and a high flight speed $-130-200 \mathrm{~km} / \mathrm{h}$.

Multifunctional unmanned complexes of the Orlan series. The main examples of the series "Orlan" are:

- "Orlan-1" (micro);

- "Orlan-3M" (mini);

- "Orlan-10" (tactical);

- Orlan-30.

Unmanned aerial vehicle complex "Orlan-3M" (Figure 4) is designed to perform panoramic and planned photo and video shooting of the area.

The "Orlan-10" UAV (Figure 4) is designed to control objects in hard-to-reach areas, can be used for search and rescue operations.

The UAV is equipped with an internal combustion engine running on conventional A-95 gasoline. The start is made from a collapsible catapult, 
landing - by parachute. The maximum speed is $150 \mathrm{~km} / \mathrm{h}$. The device has a significant flight duration -16 hours. The maximum range is $600 \mathrm{~km}$.

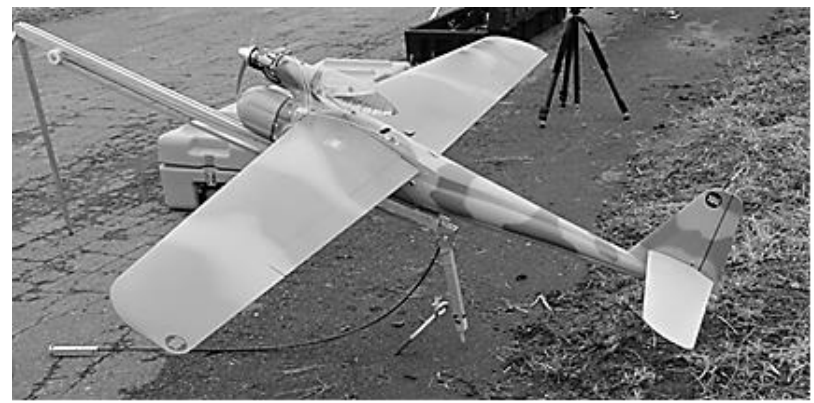

Fig. 4. UAV “Orlan-3M"

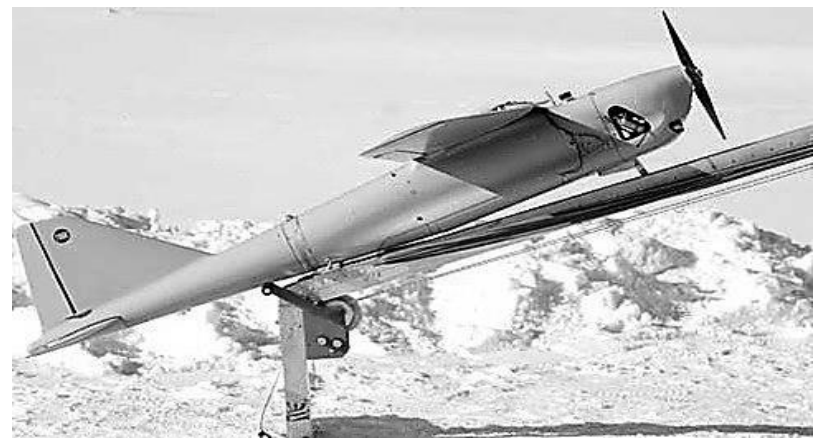

Fig. 5. UAV "Orlan-10"10

From one control point it is possible to control at once 4 UAVs "Orlan-10", thus one of them can serve as a repeater of data for others that increases the general range of action of group.

The aircraft "Dozor-600" (Figure 6) in its characteristics can be compared with the American MQ-1B. Takeoff and landing of the aircraft are carried out by aircraft. The basis of the payload should be: radar, video camera, thermal imager and camera. With appropriate modification, "Dozor-600" will be able to perform shock functions. The

10 Алімпієв А.М. Довідник учасника АТО: озброєння і військова техніка Збройних сил Російської Федерації. / Г.В. Пєвцов, Д.А. Гриб та ін. ; за заг. ред. А.М. Алімпієва. Харків. 2015. 732 с. 
device is currently under development. It is unknown whether the "Dozor-600" will go into series, or developments on it will be used to create some other, perhaps even larger UAVs.

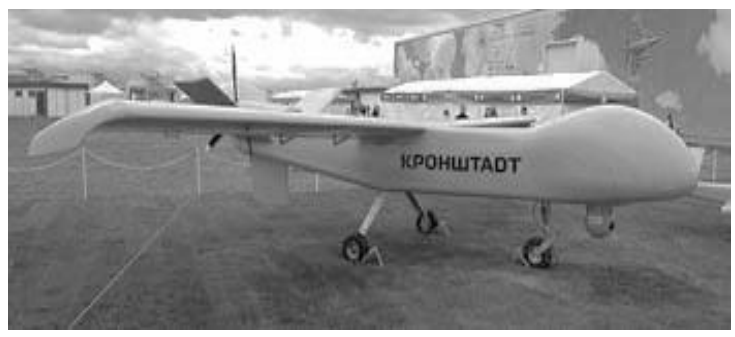

Fig. 6. UAV "Patrol-600"

It is unknown whether the "Dozor-600" will go into series, or developments on it will be used to create some other, perhaps even larger UAVs.

The main task of the aircraft "Outpost" (Figure 7) is to survey the space.

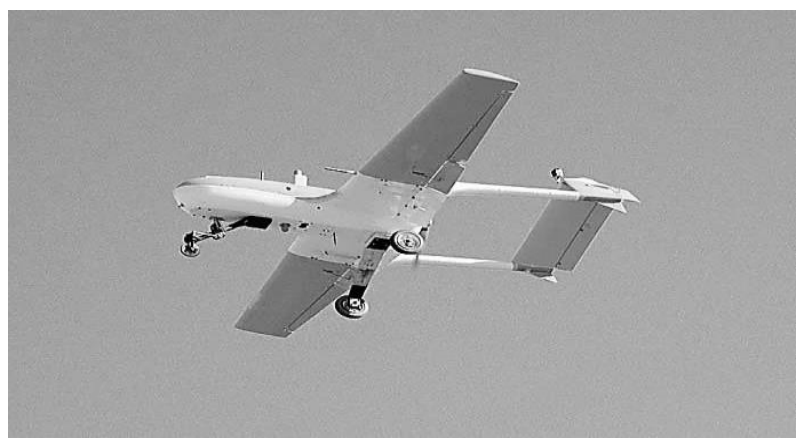

Fig. 7. UAV "Outpost"11

The UAV has a system of two independent gyroscopes, GPS sensors are also duplicated, equipped with a multifunctional video surveillance system with video capture cards, a powerful infrared camera with a highresolution cooling matrix.

11 Алімпієв А.М. Довідник учасника АТО: озброєння і військова техніка Збройних сил Російської Федерації. / Г.В. Пєвцов, Д.А. Гриб та ін. ; за заг. ред. А.М. Алімпієва. Харків. 2015. 732 с. 
Effective counteraction of UAVs requires their timely detection, which can be visual, acoustic, optical, radar and radio engineering.

Radio engineering units of RT currently perform only radar and visual detection ${ }^{12}$. Radar means include radars, which by purpose will be divided into radars of combat and duty modes.

The main radars of the next mode are radar 5H84A and modernized radar 5H84MA, radar P-18 and its modifications radar P-18MU, radar P-18MA, radar P-18 "Malachite". The main radars of combat mode are radar 19Zh6, radar 35D6 and modernized radar 35D6M, radar P-37 (P-37R), radar 79K6.

The experience of the conflict in Donbass has shown that the detection distances of small UAVs at different values of SSA and depending on the range of radar range from hundreds of meters (for SSA $0.01 \mathrm{~m} 2$ ) to $20 \mathrm{~km}$ (for SSA $0.1 \mathrm{~m} 2$ ), which greatly complicates the work operator for their timely detection. There are currently no special means of timely detection of such aircraft ${ }^{13}$.

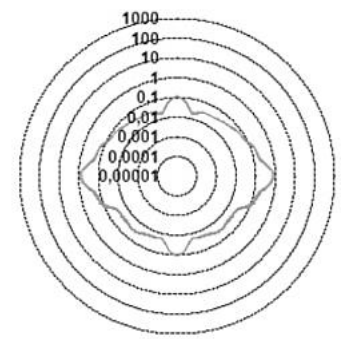

A

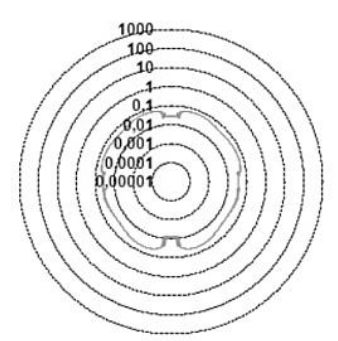

B

Fig. 8. Diagrams of incoherent EPR (m2) UAV “Orlan":

$$
a-\lambda=10 \mathrm{~cm}, \quad b-\lambda=1.8 \mathbf{m}^{14}
$$

12 Шамко В.С. Особливості застосування Повітряних Сил в умовах гібридної війни. Новітні технології-для захисту повітряного простору : тези допов. 13-ої наук. конф. Харк. нац. ун-ту Повітряних Сил ім. Івана Кожедуба (Харків 12-13 квіт. 2017). Харків : ХУПС, 2017. С. 10-11.

${ }^{13}$ Вишневський С.Д., Бейліс Л.В., Климченко В.Й. Потенційні можливості РЛС РТВ 3 виявлення оперативно-тактичних та тактичних безпілотних літальних апаратів. Наука $і$ техніка Повітряних Сил Збройних сил Украӥни. 2017. Вип. 2 (27). С. 92-98.

${ }_{14}$ Там само. 
After analyzing the UAVs that were recorded in the Donbass, the possibility of detecting these UAVs by modern radar stations 35D6, 19ZH6, "Malachite" and P-18MA was investigated. There are no experimental data on the reflective properties of these UAVs, so the study used the calculated values of the effective reflective surface of the UAV "Orlan-10", which are shown in Figure 8.

Since the potential capabilities of the radar to detect UAVs were analyzed, the detection zones of these targets were calculated assuming the location of the radar at ideal positions. The vertical section of the detection zone is generally described by the expression:

$$
r(\varepsilon)=r_{0} F_{0}(\varepsilon) F_{e}(\varepsilon),
$$

$r_{0}$ - the maximum range of detection of the radar target in free space;

$F_{0}(\varepsilon)$ - AP in free space;

$F_{e}(\varepsilon)$ - interference factor of the Earth.

The shapes and sizes of UAV detection zones by "Malachite" radar stations (P-18MA) and 19Zh6 (35D6) are shown in Figures 9-11" .

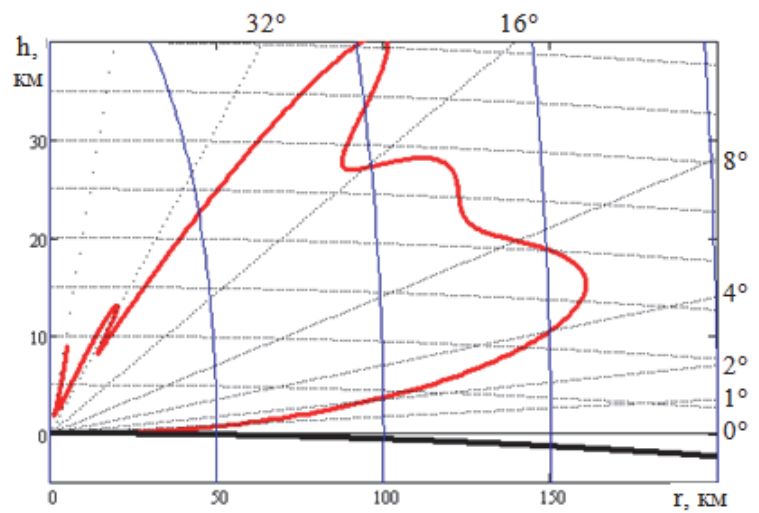

Fig. 9. Vertical section of the detection zone of operational and tactical UAV radar "Malachite" (P-18MA) when working with a standard antenna

15 Вишневський С.Д., Бейліс Л.В., Климченко В.Й. Потенційні можливості РЛС РТВ 3 виявлення оперативно-тактичних та тактичних безпілотних літальних апаратів. Наука і техніка Повітряних сил Збройних Сил Украӥни. 2017. Вип. 2 (27). С. 92-98. 


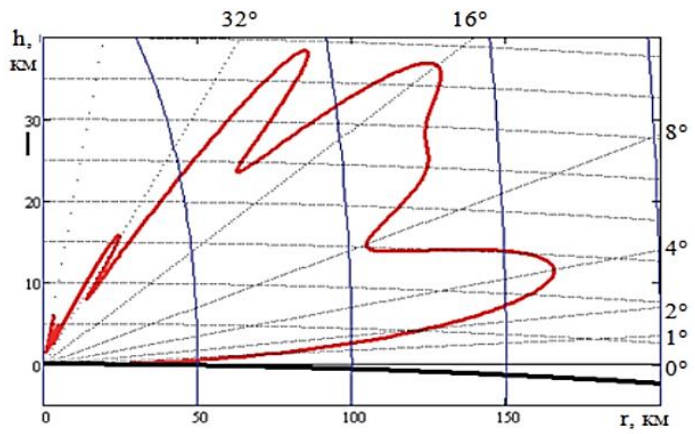

Fig. 10. Vertical section of the detection zone of operational and tactical UAV radar "Malachite" (P-18MA) when raising the antenna in two sections

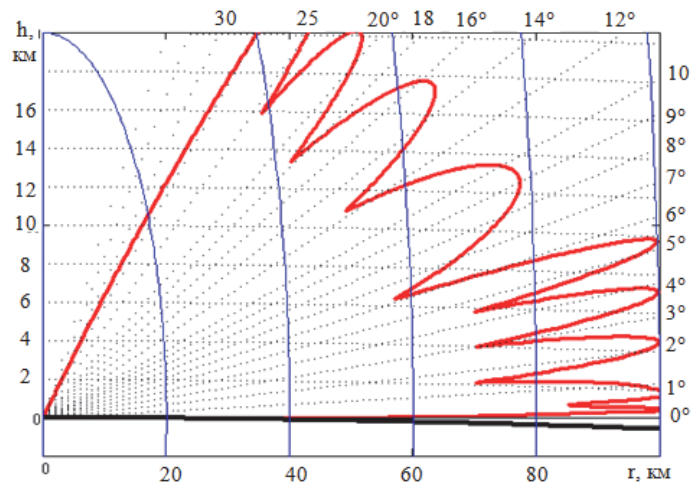

Fig. 11. Vertical section of the detection zone of operational and tactical UAV radar 35D6 (19Zh6) (P-18MA) in the next mode ${ }^{16}$

The calculations allowed to determine that modern radars can provide detection of UAV-type "Orlan-10" at altitudes of $100 \mathrm{~m}$ - at ranges of $15 \ldots 30 \mathrm{~km}$, at altitudes of more than $500 \mathrm{~m}-$ at ranges of $50 \ldots 60 \mathrm{~km}$, and at altitudes greater than $1000 \mathrm{~m}$ - at distances of $70 \ldots 90 \mathrm{~km}$.

Therefore, the detection of UAVs can be carried out by radar.

${ }^{16}$ Вишневський С.Д., Бейліс Л.В., Климченко В.Й. Потенційні можливості РЛС РТВ 3 виявлення оперативно-тактичних та тактичних безпілотних літальних апаратів. Наука і техніка Повітряних Сил Збройних сил України. 2017. Вип. 2 (27). С. 92-98. 
But the new round of conflict in Nagorno-Karabakh, which intensified a few weeks ago, is very different from previous fighting. It is obvious that in this war a special, even dominant role is played by the new modern armament, which is increasingly gaining a leading position $^{17}$. We are talking about unmanned aerial vehicles - UAVs. It was they who began to define a new strategy and tactics of armed confrontation in theaters of war. Based on this, we can safely say that the example of the conflict in Karabakh is formed something like "wars of the future", when the battle is driven by cars controlled at a distance.

$\mathrm{RT}$ are the main sources of airspace information. They are radar means of $\mathrm{AO}$ detection and coordinate measurement.

Thus, according to the classic scenario of the war of the future, the Azerbaijani troops began their operation to neutralize the means of airspace control and involved drones of various types, operating within clearly defined tasks. To control the airspace of Karabakh, radiocontrolled drones based on old An-2 aircraft were used, the appearance of which over certain areas (especially at night) provoked the enemy to open fire (with the cost of scarce missiles), which made it possible to distinguish the positions of existing anti-aircraft missile systems layouts.

All data was transmitted online to the control point, and the detected targets were immediately destroyed by artillery and drone strikes. Thus, neutralized the short-range defense of airspace with the confirmed destruction of 10 to 15 Anti-aircraft missile systems type "Wasp", several type "Arrow-10" and electronic warfare stations (including the latest Russian complex to combat small UAVs "Repellent-1"). Later, the S-300 anti-aircraft missile systems and the P-18 radar were also destroyed by an air strike. As a result, one of the main factors of defense stopped working.

We can say that the military conflicts of recent years have shown that with the advent of homing weapons, active radars have become quite vulnerable, so there is a question of more effective choice of radar method as a way to control enemy airspace.

Despite this, the means of passive location are currently used very little. The role of passive detection systems at this stage of development becomes especially important in connection with the almost phenomenal growth of energy characteristics of active noise interference, protection against which by means of active radar becomes ineffective.

${ }^{17}$ Інтернет-ресурс. URL: https://www.bbc.com/ukrainian/features-54434848. 


\section{Detection of low-visibility air objects at the expense of using a multi-position system of passive receivers}

Military conflicts in recent years have shown that with the advent of homing weapons, active radars have become quite vulnerable, so the question arises of a more effective choice of radar method as a way to control airspace.

An important class of such systems is the method of passive radar, which provides all the stages of obtaining information about targets, such as detection, measurement of coordinates, as well as motion parameters. AO transmitters (aeronautical navigation, location, communication, sources of artificial interference), as well as objects that have thermal or radar contrast with the environment can be sources of radiation.

Hence, we can say that the main sources of such signals, for example, from the aircraft, which is a classic representative of the $\mathrm{AO}$ are:

- radar detection and aeronautical complex;

- radio altimeters.

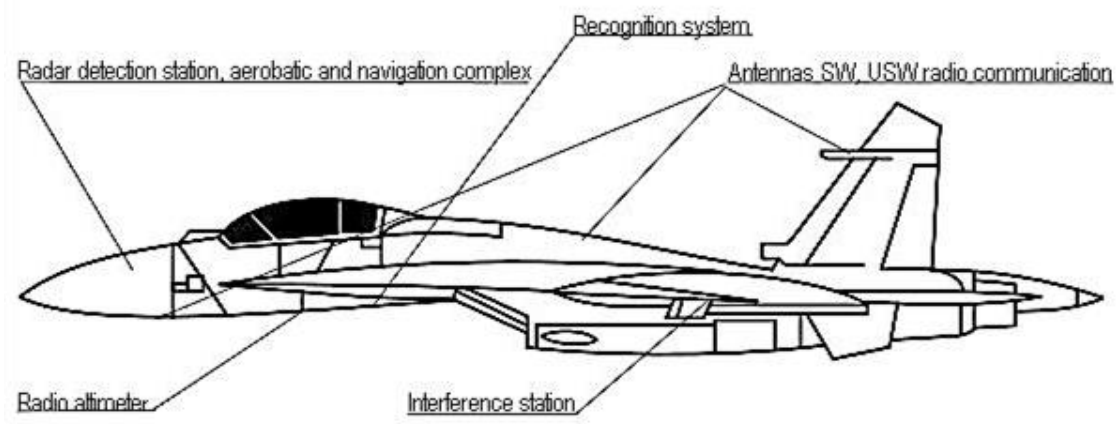

Fig. 12. Radiation sources ${ }^{18}$

18 Худов Г.В, Місюк Г.В., Сова О.В. Порівняльна оцінка потенційних точностей визначення координат повітряних об'єктів у багатопозиційній пасивній системі. Новітні технології - для захисту повітряного простору : XV міжн. наук. конф. : тези допов. Харків : ХНУПС, 2019. С. 224. 
These signals can be considered as sources of information that will determine the characteristics of the signals (operating frequency, spectrum width, power, etc.).

Thus, the paper proposes to use a multi-position system of passive receivers to increase the efficiency of detection of AO (figure 13) ${ }^{19}$.

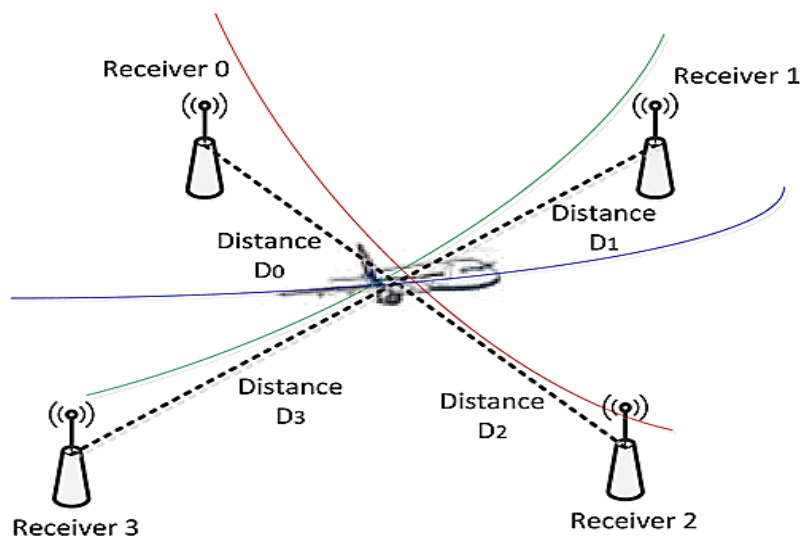

Fig. 13. Multi-position system of passive receivers

The information of such a passive system can be used as an additional at the command posts of radio units and to create and maintain a continuous radar field at low and medium altitudes.

The use of a passive multi-position system of receivers in comparison with single-position radars allows to increase the accuracy of measuring the spatial coordinates of the software and reliability due to the excessive number of receiving positions.

In addition, the passive multi-position system provides complete secrecy and, as a consequence, high survivability ${ }^{20}$.

On the other hand, unlike the active radar method, the passive system does not allow to determine the distance to the air object according to the signal reception by only one receiver, which is a significant disadvantage. Therefore, to determine the coordinates of the AO it is necessary to use a multi-position system of passive receivers located at a

19 Черняк В.С. Многопозиционная радиолокация. Радио и связь, Москва. 1993. $416 \mathrm{c}$.

20 Там само. 
certain distance from each other (base). In a passive multi-position system, the AO coordinates are determined by measuring the relative signal delays from the AO. In this case, you can omit the space survey and use directional antennas. Unlike active radar, in passive radar it is not known in advance at what frequency this or that software emits, therefore the whole range of certain frequencies is scanned. In passive radar systems, the angular coordinates of objects are measured by known direction-finding methods, namely angular, difference-range and angular-difference-range methods ${ }^{21}$.

The most common method of determining the coordinates in a passive multi-position receiver system is the difference-range method, which is based on measuring the difference in time delay (Time Difference of Arrival (TDOA)) of the signal emitting AO in the direction of the system receivers ${ }^{22}$.

The signal emitted by the AO will be received by the system receivers at different times, depending on the distance between the software receivers. The time difference between the two receivers is compared with the hyperboloid (in three-dimensional space) on which the AO is located (figure 14) ${ }^{23}$.

The difference-range method is based on measuring the relative delay of signals received at three reception points and determining the line of movement (hyperbola), as well as subtracting the coordinates of the point of intersection of the lines of movement.

Let the reception points be at spaced observation points A1, A2, A3, $\mathrm{AO}-$ at point $\mathrm{M}$. The distances between points $\mathrm{A} 1, \mathrm{~A} 2, \mathrm{~A} 3$ are denoted by $\mathrm{d} 12, \mathrm{~d} 23$, respectively, the distances from the reception points to the AO are denoted by D1, D2, D3. The foci of hyperbole coincide with the points of observation.

${ }^{21}$ Місюк Г. В. Порівняльний аналіз методів визначення координат повітряних об'єктів у багатопозиційній пасивній системі. Перспективи розвитку озброєння та військової техніки Сухопутних військ : тези допов. міжнар. наук.-техн. конф. (16-17 трав. 2019 р.). Львів, 2019. С. 78.

${ }^{22}$ Khudov H. The Bayes Rule of Decision Making in Joint Optimization of Search and Detection of Objects in Technical Systems / H. Khudov, I. Khizhnyak, F. Zots, G. Misiyuk, O. Serdiuk. International Journal of Emerging Trends in Engineering Research. 2020. No. 8 (1). Pp. 7-12. DOI: 10.30534/ijeter/2020/02812020.

23 Худов Г.В, Місюк Г.В., Сова О.В. Порівняльна оцінка потенційних точностей визначення координат повітряних об'єктів у багатопозиційній пасивній системі. Новітні технологї - для захисту повітряного простору : XV міжн. наук. конф. : тези допов. Харків : ХНУПС, 2019. С. 224. 


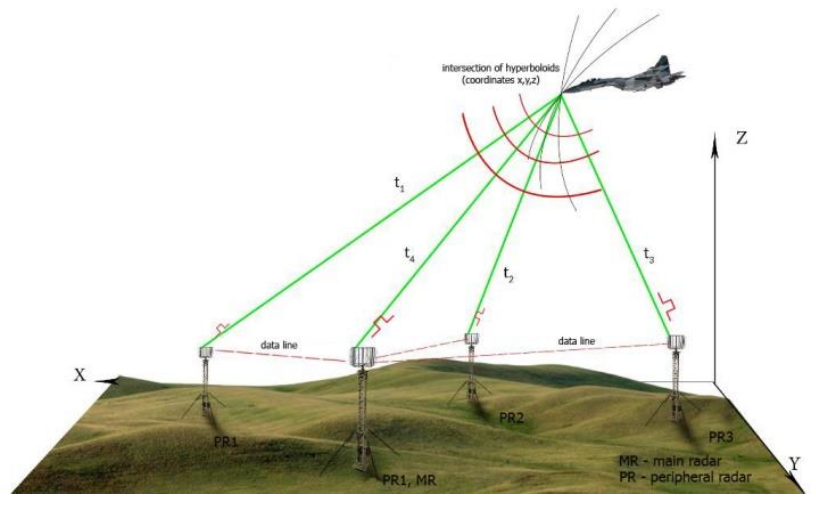

Fig. 14. Points of reception of AO signals

The differences in distances are determined by measuring the relative delay of the signals between the receiving points and are denoted by:

$$
P_{12}=\text { const }=D_{1}-D_{2} \text { and. } P_{23}=\text { const }=D_{2}-D_{3} \text {. }
$$

The spatial position of the AO is determined by three distance differences that were measured at the receiving points. The coordinates of the $\mathrm{AO}$ are defined as the point of intersection of the hyperboloids of rotation.

Usually the bases $\mathrm{d} 12$ and $\mathrm{d} 23$ are not on the same line, but at an angle of $60^{\circ}$ to $90^{\circ}$.

The linear error of the method is determined by the expression (2):

$$
\sigma_{\text {Л }}\left(D_{1}-D_{2}\right)=\frac{\sigma\left(D_{1}-D_{2}\right)}{2 \sin \phi},
$$

де $\sigma-$ standard deviation of the definition $\mathrm{P}_{12}$; $\varphi$ - angle $\mathrm{A}_{1} \mathrm{MA}_{2}$.

The difference-range method is based on measuring the difference in the course of signals to the receiving positions. This method allows the use of both pulsed and continuous signals, including noise and noise. The method is especially effective in cases where basic correlation processing is used to calculate the stroke difference, in which the type of signals does not matter. 
Thus, knowing the range of operation of electronic equipment of UAVs, it is possible to determine the frequency range of passive receivers, which are combined into a multi-position system ${ }^{24}$.

Thus, knowing the range of operation of electronic equipment of UAVs, it is possible to determine the frequency range of passive receivers, which are combined into a multi-position system.

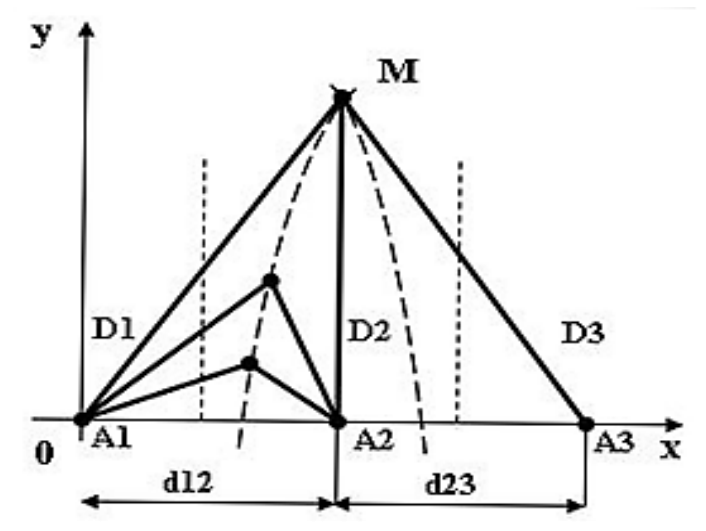

Fig. 15. Differential-range detection method AO provisions ${ }^{25}$

\section{CONCLUSIONS}

The paper analyzes the implementation of airspace control tasks. It is established that the use of traditional methods to increase the efficiency of detection of small $\mathrm{AO}$ leads to an increase in the required number of radars, increase power consumption and, consequently, to increase the cost of creating and maintaining the next radar field. The use of the passive method of radar to increase the efficiency of detection of AO by state space control systems is proposed.

In addition, the multi-position system of passive receivers provides complete secrecy and, as a consequence, high survivability. The main

24 Худов Г.В, Місюк Г.В., Сова О.В. Порівняльна оцінка потенційних точностей визначення координат повітряних об'єктів у багатопозиційній пасивній системі. Новітні технологіі - для захисту повітряного простору : XV міжн. наук. конф. : тези допов. Харків : ХНУПС, 2019. С. 224.

25 Місюк Г.В. Порівняльний аналіз методів визначення координат повітряних об'єктів у багатопозиційній пасивній системі. Перспективи розвитку озброєння та військової техніки Сухопутних військ : тези допов. міжнар. наук.-техн. конф. (16-17 трав. 2019 р.). Львів, 2019. С. 78. 
attention is paid to the multi-position system of passive receivers. In passive radar systems, the measurement of angular coordinates of objects is performed by known methods of direction finding, namely angular, difference-range and angular-difference-range methods.

The most common method of determining coordinates in a passive multi-position receiver system is the difference-rangefinder method, which is based on measuring the difference in delay time. The analysis of radar equipment signals, which are directly a source of information in the passive radar system, is carried out to determine the tactical and technical characteristics of receivers when detecting air objects by a multi-position system of passive receivers in a certain direction. Knowing the TTC of these air objects, namely the characteristics of the signals of the onboard radio equipment, will allow to allocate priority frequencies for tuning the multi-position system of receivers in a particular direction.

\section{SUMMARY}

The analysis of tendencies of development of small air objects is carried out and it is shown that one of tendencies is decrease in their radar visibility. Small values of the ESA $\left(0.005 \ldots 0.3 \mathrm{~m}^{2}\right)$ of modern and promising small AO cause a deterioration in the efficiency of their detection.

The analysis of unmanned aerial vehicles, which were recorded in the East of Ukraine during airspace control, is carried out.

It is established that the use of traditional methods to increase the efficiency of $\mathrm{AO}$ detection leads to an increase in the required number of radars, increase power consumption and, as a consequence, to increase the cost of creating and maintaining the next radar field.

The analysis of the main TTC of the radar, and their capabilities for AO detection and existing methods to improve the efficiency of detection of AO by state space control systems.

The method of increasing the efficiency of AO detection by state space control systems, namely the passive method of radar, is considered.

It is established that the use of a multi-position system of passive receivers increases the efficiency of AO detection.

\section{REFERENCES}

1. Ковалевський С.М., Худов Г.В., Боровий В.I. Перспективи розвитку засобів повітряного нападу як об'єктів радіолокаційного 
виявлення. Системи озброєння та військова техніка. 2014. Вип. № 4(40). С. 31-35.

2. Ковалевський С.М., Пєвцов Г.В., Худов Г.В. Пропозиції щодо створення скритого маловисотного радіолокаційного поля в умовах ведення сучасних мережецентричних та гібридних війн. Наука $i$ техніка Повітряних Сил Збройних сил Украӥни. Харків : ХУПС, 2015. Вип. № 1 (18). С. 77-81.

3. Чепурний В.А, Бардаков М.В., Худов Г.В. Аналіз тенденцій розвитку та застосування розвідувальних безпілотних апаратів у сучасних мережецентричних та гібридних війнах. Наука $i$ техніка Повітряних Сил Збройних сил України. Харків : ХНУПС, 2015. Вип. № 4 (21). С. 24-28.

4. Романченко I.C. Теорія і практика боротьби з малорозмірними низьколітними цілями (оцінка можливостей, тенденції розвитку засобів протиповітряної оборони) : монографія / О.М. Загорка, С.Г Бутенко, О.В. Дейнега. Житомир. 2011. С. 344.

5. Ерёмин Г.В. Малоразмерные беспилотники - новая проблема для ПВО. Тамбов, 2015. URL: http://www.armynews.ru/2015/02/ malorazmernye-bespilotniki-novaya-problema-dlya-pvo.

6. Сухаревський O.I., Василець В.О., Ряполов I.С. Оцінювання параметрів зон виявлення безпілотного літального апарату «Орлан10» радіолокаційними засобами самохідного зенітного ракетного комплексу 9К33М3 «Оса-АКМ». Системи озброєння $i$ військова техніка. 2016. Вип. № 4(48). С. 13-18.

7. Алімпієв А.М. Довідник учасника АТО: озброєння і військова техніка Збройних сил Російської Федерації. / Г.В. Пєвцов, Д.А. Гриб та ін. ; за заг. ред. А.М. Алімпієва. Харків. 2015. 732 с.

8. Шамко В.Є. Особливості застосування Повітряних Сил в умовах гібридної війни. Новітні технології - для захисту повітряного простору : тези допов. 13-ої наук. конф. Харк. нац. унту Повітряних Сил ім. Івана Кожедуба (Харків 12-13 квіт. 2017). Харків : ХУПС, 2017. С. 10-11.

9. Вишневський С.Д., Бейліс Л.В., Климченко В.Й. Потенційні можливості РЛС РТВ 3 виявлення оперативно-тактичних та тактичних безпілотних літальних апаратів. Наука $i$ техніка Повітряних Сил Збройних сил Украӥни. 2017. Вип. 2 (27). С. 92-98.

10. Інтернет-pecypc. URL: https://www.bbc.com/ukrainian/features54434848

11. Худов Г.В, Місюк Г.В., Сова О.В. Порівняльна оцінка потенційних точностей визначення координат повітряних об'єктів у 
багатопозиційній пасивній системі. Новітні технології - для захисту повітряного простору : XV міжн. наук. конф. : тези допов. Харків : ХНУПС, 2019. С. 224.

12. Черняк В.С. Многопозиционная радиолокация. Радио и связь, Москва. 1993. 416 с.

13. Місюк Г.В. Порівняльний аналіз методів визначення координат повітряних об'єктів у багатопозиційній пасивній системі. Перспективи розвитку озброєння та військової техніки Сухопутних військ : тези допов. міжнар. наук.-техн. конф. (16-17 трав. 2019 р.). Львів, 2019. С. 78.

14. Khudov H. The Bayes Rule of Decision Making in Joint Optimization of Search and Detection of Objects in Technical Systems / H. Khudov, I. Khizhnyak, F. Zots, G. Misiyuk, O. Serdiuk. International Journal of Emerging Trends in Engineering Research. 2020. No. 8 (1). Pp. 7-12. DOI: 10.30534/ijeter/2020/02812020.

Information about authors: Misiyuk G. V.,

Graduate Student at the Department of Tactics of Radio-Technical Troops

Ivan Kozhedub Air Force University 77/79, Sumska str., Kharkiv, 61023, Ukraine

Popov S. E.,

Candidate of Military Sciences, Professor at the Department of Radio and Special Forces Aviation and Air Defense Institute of the National Defense University of Ukraine named after Ivan Cherniakhovskiy 28, Povitroflotskiy avenue, Kyiv, 03049, Ukraine 